\title{
Adult onset egg allergy: a case report
}

\author{
Elisa Maria Cremonte ${ }^{1}$, Eugenia Galdi ${ }^{2}$, Chiara Roncallo², Elisa Boni ${ }^{3 *}$ and Luigi Giovanni Cremonte ${ }^{2}$
}

\begin{abstract}
Background: Egg allergy is one of the most frequent food allergies in childhood while adult onset of egg allergy is a rare condition.

Case presentation: We report the case of a 30 years old man sent to our center in order to investigate gastrointestinal symptoms occurring since 2 years after egg and derivatives intake. He did not suffer from egg or other food allergies in childhood. He is an active smoker with a contact dermatitis related to nickel and mild allergic rhinoconjunctivitis to grass pollen. Skin prick test and serum specific lgE to egg were performed and revealed sensitization to egg proteins.
\end{abstract}

Conclusions: Even though IgE-mediated egg allergy affects children, this report witnesses a rare case of adult onset. Keywords: Egg allergy, Food allergy, Ovomucoid, Ovalbumin

\section{Introduction}

Although egg allergy prevails in pediatric population, some studies have described the persistence or newly onset egg sensitization through adults [1]. A failure in oral tolerance or a breakdown in previously acquired tolerance results in food hypersensitivity. Egg allergy is frequently observed during the first years of life, according to its alimentary introduction. There is a possible resolution of egg allergy within 10-15 years from the diagnosis. Symptoms include early onset of IgE-mediated urticaria, eczema, abdominal pain and vomiting. In some more severe cases anaphylaxis with dyspnea and hypotension can occur. Non-IgE mediated symptoms include eosinophilic diseases of the gut or egg-induced enterocolitis [2, $3]$. Consumption of baked egg by raw egg allergic children does not seem to either induce or accelerate the development of tolerance in this population [4]. There is evidence of a strong association between sensitization to egg during infancy and, later, to inhalant allergens.

\footnotetext{
*Correspondence: elisa.boni@ausl.bologna.it

${ }^{3}$ Laboratorio Unico Metropolitano, Maggiore Hospital AUSL Bologna, Largo Nigrisoli n. 2, 40133 Bologna, Italy

Full list of author information is available at the end of the article
}

The rare adult-onset egg allergy is often associated with previous personal history of atopy or other food intolerances [5-7]. Some studies have shown that stress conditions or alteration of intestinal microbiota could be responsible for the loss of tolerance toward some food antigens [1]. Intestinal inflammatory disorders, such as Crohn disease, celiac disease, or ulcerative colitis favor the development of food allergy by altering intestinal permeability. It has been reported a case of late-onset egg allergy following the diagnosis of Hodgkin's lymphoma and start of chemotherapy and the authors speculated an alteration involving bowel mucous membrane [8].

Diagnosis of egg allergy includes anamnesis, skin prick tests and serum specific IgEs [9]. The most significant antigenic components of egg white are ovomucoid (Gal d 1-thermo stable), ovalbumin (Gal d 2-thermolabile), ovotransferrin (Gal d 3), and lysozime (Gal d 4). Depending on the sensitization pattern, patients with egg allergy can manifest symptoms with cooked or raw egg. In some patients a relationship between hypersensitivity secondary to bird antigens exposure and allergy to egg yolk has been documented [1]. This is known as bird-egg syndrome [10]. It derives from the sensitization to the chicken serum protein called alpha livetin (Gal d 5), that is also represented in egg yolk. It is characterized original author(s) and the source, provide a link to the Creative Commons licence, and indicate if changes were made. The images or other third party material in this article are included in the article's Creative Commons licence, unless indicated otherwise in a credit line to the material. If material is not included in the article's Creative Commons licence and your intended use is not permitted by statutory regulation or exceeds the permitted use, you will need to obtain permission directly from the copyright holder. To view a copy of this licence, visit http://creativecommons.org/licenses/by/4.0/. The Creative Commons Public Domain Dedication waiver (http://creativeco mmons.org/publicdomain/zero/1.0/) applies to the data made available in this article, unless otherwise stated in a credit line to the data. 
by respiratory and gastrointestinal symptoms after egg intake or after exposure to feathers and droppings of birds. Allergy to other aeroallergens is frequently documented in individuals with bird-egg syndrome.

Currently, there is active research on trying oral immunotherapy to desensitize people to egg allergens [11-13].

\section{Case report}

We report a rare case of adult-onset egg allergy. A 30 years old man referred to our center in order to investigate gastrointestinal symptoms (vomit, abdominal pain and diarrhea) that have been occurring for 2 years. He reports that symptoms occur within few minutes after egg or egg derivatives ingestion: pasta carbonara, mayonnaise, fried egg and meringue. Conversely, he tolerates baked egg (at cooking temperature greater than $160{ }^{\circ} \mathrm{C}$ for $25-30 \mathrm{~min}$ ) independently from a flour matrix presence.

No familial history for atopy is present. In childhood, he did not suffer from atopic dermatitis nor egg or other food allergies while a history of contact dermatitis related to nickel and mild allergic rhinoconjunctivitis to grass pollen is reported. He is not affected by immunodeficiency or chronic inflammatory bowel disease, nor disorders affecting the biliary tract or intolerance to lactose. $\mathrm{He}$ is an active smoker. He does not have any occupational exposure risk.

\section{Materials and methods}

Skin prick test with a large panel of commercial food and common inhalant allergen extracts (Lofarma, Milan, Italy) and serum specific IgEs (Thermo Fisher Scientific, US) to egg extract and to ovomucoid, ovalbumine and lysozyme were performed. According to our laboratory ranges, values $\geq 0.10 \mathrm{kUa} / \mathrm{l}$ are considered positive.

Prick by prick test with white and yolk from raw egg and cooked egg was done. The egg was boiled at $100{ }^{\circ} \mathrm{C}$ for ten minutes and yolk was mechanically separated from white.

\section{Results}

The prick test with commercial extracts showed a positive response to egg white and grasses, while animal epithelia, dust mites and molds were negative.

Prick by prick test was positive for raw and boiled egg white (diameter of wheals were $15 \mathrm{~mm} \times 8 \mathrm{~mm}$ and $4 \mathrm{~mm} \times 2 \mathrm{~mm}$ respectively).

Serum specific IgEs were positive for egg white $(3.52 \mathrm{kUa} / \mathrm{l})$, showing a strong positivity for Gal d 2-ovalbumin $(8.87 \mathrm{kUa} / \mathrm{l})$ and low positive value for $\mathrm{Gal} \mathrm{d}$ 1-ovomucoid $(0.10 \mathrm{kUa} / \mathrm{l})$ according to laboratory ranges (positive result $\geq 0.10 \mathrm{kUa} / \mathrm{l}$ ).
Diagnosis of egg allergy was confirmed. The patient was advised to avoid ingestion of egg and egg derivatives. Selfinjectable epinephrine and adequate pharmacotherapy in the event of accidental ingestion was delivered.

\section{Discussion}

Adult onset egg allergy has been rarely reported in literature and, generally, it is preceded by a certain degree of egg hypersensitivity in childhood [14]. Our case is noteworthy and peculiar because symptoms occurred only in adulthood and history of occupational or home exposure to allergens was absent. Moreover, in our patient the clinical presentation of IgE mediated egg allergy is atypical since other extra-gastrointestinal symptoms are not present but clinical correlation between strong ovalbumin sensitization and occurrence of symptoms with raw egg or with cooked egg at low temperature is strong. The patient did not complain about respiratory symptoms and skin prick test were negative for animal fur, so bird-egg syndrome was excluded.

We may speculate that the clinical presentation of egg allergy, characterized by gastrointestinal disorders in the absence of any systemic symptom, is dependent from the presence of an intact intestinal mucosa.

\section{Acknowledgements}

Not applicable.

Authors' contributions

EG and CR collected data. EC and LC analyzed the data and wrote the draft paper. EB participated in draft revision, data analysis and editing of the final draft. All authors read and approved the final manuscript.

\section{Funding}

No funds were received for this paper.

Availability of data and materials Not applicable.

\section{Declarations}

Ethics approval and consent to participate Not applicable.

\section{Consent for publication}

Consent for publication was obtained from the patient.

\section{Competing interests}

The authors declare that they have no competing interests.

\section{Author details}

${ }^{1}$ Internal Medicine Resident, University of Pavia, Pavia, Italy. ${ }^{2} \mathrm{SS}$ of Allergology ASL AL, Novi Lingure, AL, Italy. ${ }^{3}$ Laboratorio Unico Metropolitano, Maggiore Hospital AUSL Bologna, Largo Nigrisoli n. 2, 40133 Bologna, Italy.

Received: 5 July 2021 Accepted: 3 September 2021

Published online: 04 October 2021 


\section{References}

1. Unsel M, Sin AZ, Ardeniz O, Erdem N, Ersoy R, Gulbahar O, Mete N, Kokuludağ A. New onset egg allergy in an adult. J Investig Allergol Clin Immunol. 2007;17(1):55-8.

2. Caubet JC, Wang J. Current understanding of egg allergy. Pediatr Clin North Am. 2011;58(2):427-43.

3. Tse KY, Christiansen SC. Eosinophilic gastroenteritis due to egg allergy presenting as acute pancreatitis. Allergy Rhinol. 2015;6(1):80-1.

4. Netting M, Gold M, Quinn P, El-Merhibi A, Penttila I, Makrides M. Randomised controlled trial of a baked egg intervention in young children allergic to raw egg but not baked egg. World Allergy Organ J. 2017;10(1):22

5. Benhamou AH, Caubet JC, Eigenmann PA, Nowak-Wegrzyn A, Marcos CP, Reche M, Urisu A. State of the art and new horizons in the diagnosis and management of egg allergy. Allergy. 2010;65(3):283-9.

6. Čelakovská J, Ettlerová K, Ettler K, Bukač J. Egg allergy in adolescent and adult patient suffering from atopic dermatitis - association with concomitant allergic diseases. Acta Medica. 2015;58(1):9-14.

7. Mathew P, Pfleghaar JL. Egg allergy. Treasure Island: StatPearls Publishing; 2020.

8. Calado G, Machado D, Ribeiro C, Loureiro G, Tavares B, Pereira C, Cunha R, Chieira C. Hodgkin's lymphoma and late onset egg allergy: is there a causal relationship? Allergol Immunopathol. 2011;39(4):242-3.

9. Ehlers AM, Otten HG, Wierzba E, Flügge U, Le TM, Knulst AC, Suer W. Detection of specific IgE against linear epitopes from Gal 11 has additional value in diagnosing hen's egg allergy in adults. Clin Exp Allergy. 2020;50(12):1415-23.

10. Hemmer W, Klug C, Swoboda I. Update on the bird-egg syndrome and genuine poultry meat allergy. Allergo J Int. 2016;25:68-75.

11 Romantsik O, Tosca MA, Zappettini S, Calevo MG. Oral and sublingual immunotherapy for egg allergy. Cochrane Database Syst Rev. 2018:4(4):CD010638. https://doi.org/10.1002/14651858.CD010638.pub3.

12. Dona DW, Suphioglu C. Egg allergy: diagnosis and immunotherapy. Int J Mol Sci. 2020;21(14):5010

13. Muraro A, Werfel T, Hoffmann-Sommergruber K, Roberts G, Beyer K, Bindslev-Jensen C, Cardona V, Dubois A, duToit G, Eigenmann P, Rivas MF, Halken S, Hickstein L, Høst A, Knol E, Lack G, Marchisotto MJ, Niggemann B, Nwaru BI, Papadopoulos NG, Poulsen LK, Santos AF, Skypala I, Schoepfer A, Van Ree R, Venter C, Worm M, Vlieg-Boerstra B, Panesar S, de Silva D, Soares-Weiser K, Sheikh A, Ballmer-Weber BK, Nilsson C, de Jong NW, Akdis CA, EAACl Food Allergy and Anaphylaxis Guidelines Group. EAACl food allergy and anaphylaxis guidelines: diagnosis and management of food allergy. Allergy. 2014;69(8):1008-25.

14. Hu W, Katelaris CH, Kemp AS. Recurrent egg allergy in adulthood. Allergy. 2007:62(6):709

\section{Publisher's Note}

Springer Nature remains neutral with regard to jurisdictional claims in published maps and institutional affiliations.
Ready to submit your research? Choose BMC and benefit from:

- fast, convenient online submission

- thorough peer review by experienced researchers in your field

- rapid publication on acceptance

- support for research data, including large and complex data types

- gold Open Access which fosters wider collaboration and increased citations

- maximum visibility for your research: over $100 \mathrm{M}$ website views per year

At BMC, research is always in progress.

Learn more biomedcentral.com/submissions 